Supplement of Biogeosciences, 17, 6033-6050, 2020

https://doi.org/10.5194/bg-17-6033-2020-supplement

(C) Author(s) 2020. This work is distributed under

the Creative Commons Attribution 4.0 License.

(c) (1)

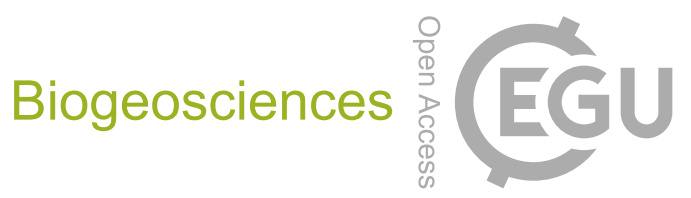

Supplement of

\title{
Interactions between biogeochemical and management factors explain soil organic carbon in Pyrenean grasslands
}

\author{
Antonio Rodríguez et al. \\ Correspondence to: Antonio Rodríguez (antonio.arharh@gmail.com)
}

The copyright of individual parts of the supplement might differ from the CC BY 4.0 License. 
2 Table S1: Variables considered in this study.

\begin{tabular}{|c|c|}
\hline Variable & Description \\
\hline \multicolumn{2}{|l|}{ Regional variables } \\
\hline \multicolumn{2}{|l|}{ Climate variables } \\
\hline MAP & Mean Annual Precipitation, mm. \\
\hline MSP & Mean Summer Precipitation, $\mathrm{mm}$. \\
\hline MAT & Mean Annual Temperature, ㅇ․ \\
\hline MST & Mean Summer Temperature, ㅇ․ \\
\hline TSIS & MST-MAT. \\
\hline Bedrock & $\begin{array}{l}3 \text { cathegories : Basic (marls and calcareous rocks), Acidic (mostly sandstones and } \\
\text { slates) or Mixed. }\end{array}$ \\
\hline \multicolumn{2}{|l|}{ Landscape variables } \\
\hline \multicolumn{2}{|c|}{ Topographical variables } \\
\hline Slope & Pendent, $\stackrel{\circ}{\text {. }}$ \\
\hline Aspect & $\operatorname{Cos}\left(\frac{0}{)}\right)$ \\
\hline Macrotopography & Protected; north-facing slopes; Exposed, south-facing slopes. \\
\hline Microtopography & Flat areas, convexities or mounds, and concavities, convexities or smooth areas. \\
\hline \multicolumn{2}{|l|}{ Soil type variables } \\
\hline Sand10 & Percentage of sands in the $10 \mathrm{~cm}$ upper layer (\%). \\
\hline Clay & Percentage of clays in the $10 \mathrm{~cm}$ upper layer (\%). \\
\hline Loam & Percentage of loams in the $10 \mathrm{~cm}$ upper layer (\%). \\
\hline $\mathrm{pH}$ & $\mathrm{pH}$ value in soil $10 \mathrm{~cm}$ upper layer. \\
\hline \multicolumn{2}{|c|}{ Management variables } \\
\hline Management & Grazer type : Cattle, Sheep, Mixed \\
\hline Grazing & $\begin{array}{l}\text { Grazing intensity, (units of big grazer (UBG ha-1) low ( } 1 \text {; lower than } 0.2 \text { UBG ha- } 1 \text { ), } \\
\text { medium ( } 2 \text {; between } 0.2-0.4 \text { UBG ha-1) and high ( } 3 \text {; up to } 0.4 \text { UBG ha-1). }\end{array}$ \\
\hline
\end{tabular}




$\begin{array}{ll}\text { Soil N } & \text { N in soil } 20 \mathrm{~cm} \text { upper layer. (\%). } \\ \text { C/N } & \text { Soil C/N ratio } \\ \text { P10 } & \text { Cations of P10 in soil } 10 \mathrm{~cm} \text { upper layer. (ppm). } \\ \text { K10 } & \text { Cations of K10 in soil } 10 \mathrm{~cm} \text { upper layer. (ppm). } \\ \text { Herbage } & \text { Avoveground biomass in } \mathrm{g} / \mathrm{m}^{2} \\ \text { Abiom } & \text { Lignin concentration by the acid detergent lingin method (\%/DM). } \\ \text { ADL } & \text { Fiber concentration by the acid detergent fiber method (\%/DM). } \\ \text { ADF } & \text { Fiber concentration by the neutro detergent fiber method (\%/DM). } \\ \text { NDF } & \text { Nitrogen in the herbage (\%/DM). } \\ \text { NH } & \text { Carbon in the herbage (\%/DM) } \\ \text { SH } & \text { CH/NH } \\ \text { ADL/NH } & \text { ADL/NH }\end{array}$

3

4

5 Table S2: Minimum, maximum, median and mean values of the continuous predictors of this

6 study. Units are shown in Table S1. MAT: mean annual temperature; MST: mean summer

7 temperature; TSIS: mean summer temperature minus mean annual temperature; MAP: mean

8 annual precipitation; MSP: mean summer precipitation; Slope: terrain slope; Aspect:; Sand: sand

9 content; Loam: loam content; Clay: clay content; $\mathrm{pH}$ : soil pH; Soil N: soil nitrogen; Soil P: soil

10 phosphorus; Soil $\mathrm{C} / \mathrm{N}$ : soil carbon to nitrogen ratio; Soil Mg: soil magnesium; Soil K: soil

11 potassium; NDF: neutro-detergent fibre; ADF: acid-detergent fibre; ADL: acid-detergent lignin;

$12 \mathrm{NH}$ : nitrogen in the herbage; $\mathrm{CH}$ : carbon in the herbage; $\mathrm{CH} / \mathrm{NH}$ : carbon to nitrogen ratio in the 
13 herbage; Abiom: aboveground biomass; NDF/CP: neutro-detergent fibre to crude protein ratio;

$14 \mathrm{ADL} / \mathrm{NH}$ : acid-detergent lignin to nitrogen in the herbage ratio.

\begin{tabular}{|c|c|c|c|c|}
\hline & Minimum & Maximum & Median & Mean \\
\hline MAT & 1.08 & 9.90 & 4.72 & 4.96 \\
\hline MST & 7.88 & 16.93 & 12.23 & 12.47 \\
\hline TSIS & 6.80 & 7.80 & 7.58 & 7.51 \\
\hline MAP & 964 & 1586 & 1252 & 1242.91 \\
\hline MSP & 169.00 & 258.00 & 235.00 & 228.90 \\
\hline Slope & 0.00 & 35.00 & 16.50 & 16.88 \\
\hline Aspect & 1.00 & 3.00 & 1.84 & 2.05 \\
\hline Sand & 3.10 & 72.20 & 32.80 & 32.67 \\
\hline Loam & 13.60 & 73.50 & 38.60 & 39.80 \\
\hline Clay & 2.90 & 68.60 & 27.25 & 27.53 \\
\hline $\mathrm{pH}$ & 3.90 & 7.80 & 5.47 & 5.74 \\
\hline Soil N & 0.11 & 1.10 & 0.46 & 0.47 \\
\hline Soil P & 4.00 & 54.00 & 11.00 & 12.98 \\
\hline Soil C/N & 4.13 & 41.60 & 12.47 & 13.39 \\
\hline Soil Mg & 2.89 & 5.99 & 4.99 & 4.92 \\
\hline Soil K & 3.40 & 6.84 & 4.99 & 5.03 \\
\hline NDF & 31.20 & 78.90 & 52.45 & 52.08 \\
\hline ADF & 17.70 & 46.60 & 29.55 & 30.07 \\
\hline ADL & 1.16 & 12.72 & 6.32 & 6.63 \\
\hline $\mathrm{NH}$ & 0.48 & 3.03 & 1.66 & 1.63 \\
\hline $\mathrm{CH}$ & 22.60 & 49.10 & 45.15 & 44.53 \\
\hline $\mathrm{CH} / \mathrm{NH}$ & 13.90 & 97.20 & 26.60 & 31.14 \\
\hline
\end{tabular}




\begin{tabular}{lllll}
\hline Abiom & 64.52 & 1224 & 308.32 & 341.91 \\
NDF/CP & 2.15 & 17.20 & 4.77 & 5.71 \\
ADL/NH & 0.50 & 14.02 & 3.92 & 4.78 \\
\hline
\end{tabular}

15

16 
17 Table S3: Chemical composition of herbage samples used for NIRS calibration. DM: dry matter;

18 MM: mineral matter or ash content; CP: crude protein; NDF: neutro-detergent fibre; ADF: acid-

19 detergent fibre; $\mathrm{ADL}$ : acid-detergent lignin; $\mathrm{NH}$ : nitrogen in the herbage; $\mathrm{CH}$ : carbon in the

20 herbage.

\begin{tabular}{lccccc}
\hline \multicolumn{1}{c}{ Parameter, \% } & $\mathrm{N}$ & Min. & Max. & Mean & SD \\
\hline DM & 67 & 91.60 & 96.73 & 93.48 & 1.39 \\
MM (Ash) & 67 & 3.58 & 19.73 & 10.10 & 3.98 \\
CP & 67 & 5.50 & 14.67 & 9.29 & 1.90 \\
NDF & 67 & 36.82 & 73.11 & 55.42 & 9.27 \\
ADF & 67 & 21.95 & 41.97 & 30.00 & 4.70 \\
ADL & 67 & 3.35 & 12.52 & 6.18 & 2.08 \\
NH & 55 & 0.75 & 2.10 & 1.44 & 0.31 \\
CH & 55 & 36.83 & 51.13 & 45.10 & 2.99 \\
\hline
\end{tabular}

21

22 Table S4: Calibration and cross validation statistics for predicting the chemical composition

23 parameters in herbage samples by NIRS analysis. DM: dry matter; MM: mineral matter or ash

24 content; CP: crude protein; NDF: neutro-detergent fibre; ADF: acid-detergent fibre; ADL: acid-

25 detergent lignin; $\mathrm{NH}$ : nitrogen in the herbage; $\mathrm{CH}$ : carbon in the herbage.

\begin{tabular}{lccccccc}
\hline Parameter & Math $^{\mathrm{a}}$ & Scatter $^{\mathrm{b}}$ & $\mathrm{R}^{2}$ & $\mathrm{r}^{2}$ & SEC & SECV & RPD \\
& treatment & correction & & & & & \\
\hline DM & $2,4,4,1$ & DT & 0.92 & 0.85 & 0.392 & 0.539 & 2.58 \\
Ash & $2,4,4,1$ & MSC & 0.83 & 0.70 & 1.583 & 0.830 & 4.80 \\
CP & $2,4,4,1$ & SNV & 0.97 & 0.94 & 0.331 & 0.451 & 4.21 \\
NDF & $2,4,4,1$ & DT & 0.83 & 0.72 & 3.756 & 4.728 & 1.96 \\
\hline
\end{tabular}




\begin{tabular}{lccccccc}
\hline ADF & $2,4,4,1$ & DT & 0.81 & 0.70 & 2.031 & 2.548 & 1.84 \\
ADL & $2,4,4,1$ & MSC & 0.80 & 0.66 & 0.900 & 1.178 & 1.77 \\
N & $2,4,4,1$ & MSC & 0.97 & 0.95 & 0.055 & 0.068 & 4.56 \\
C & $2,4,4,1$ & MSC & 0.97 & 0.95 & 0.422 & 0.581 & 5.15
\end{tabular}

$\overline{\text { DDesignations: derivate order, gap, first smoothing, and second smoothing; }{ }^{\text {b}} \text { Standard Normal }}$

27 Variance (SNV), Detrend (DT) and Multiplicative Scattering Correction (MSC) transformations.

$28 \mathrm{R}^{2}=$ coefficient of determination for calibration. $\mathrm{r}^{2}=$ coefficient of determination for cross

29 validation. $\mathrm{SEC}=$ standard error of calibration. $\mathrm{SECV}=$ standard error of cross validation. $\mathrm{RPD}=$ ratio

30 of performance to deviation (RPD=SD/SECV).

Table S5: Variance inflation values for the continuous predictors included in the GLMs. Values under 5 are considered non-problematic (Heiberger, 2017). MAP: mean annual precipitation; TSIS: mean summer temperature minus mean annual temperature; Slope: terrain slope; Clay: clay content; Soil C/N: soil carbon to nitrogen ratio; soil N: soil nitrogen; NDF: neutro-

37 detergent fibre; $\mathrm{ADL} / \mathrm{NH}$ : acid-detergent lignin to nitrogen in the herbage ratio.

\begin{tabular}{|c|c|c|c|c|c|c|c|c|}
\hline Predictor & MAP & $\mathrm{MMT}$ & Slope & Clay & $\begin{array}{l}\log (\text { soil } \\
\mathrm{C} / \mathrm{N})\end{array}$ & $\begin{array}{l}\text { Soil } \\
\mathrm{N}\end{array}$ & NDF & $\mathrm{ADL} / \mathrm{NH}$ \\
\hline $\begin{array}{l}\text { Geophysical } \\
\text { model }\end{array}$ & 1.26 & 1.16 & 1.27 & 1.22 & - & - & - & - \\
\hline $\begin{array}{l}\text { Complete } \\
\text { model }\end{array}$ & - & 1.26 & 1.32 & - & 1.58 & 1.82 & 1.32 & 1.67 \\
\hline
\end{tabular}




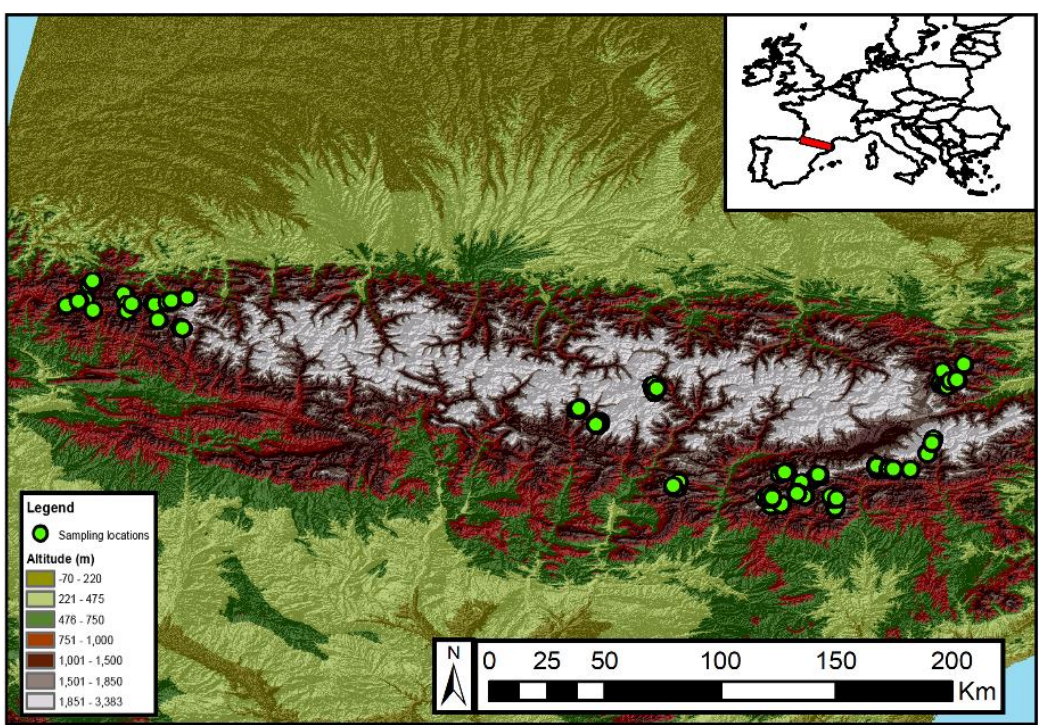

40

41 Figure S1: Map of the study area. Points indicate sampling locations.

42 


\section{PASTUS Database workflow}
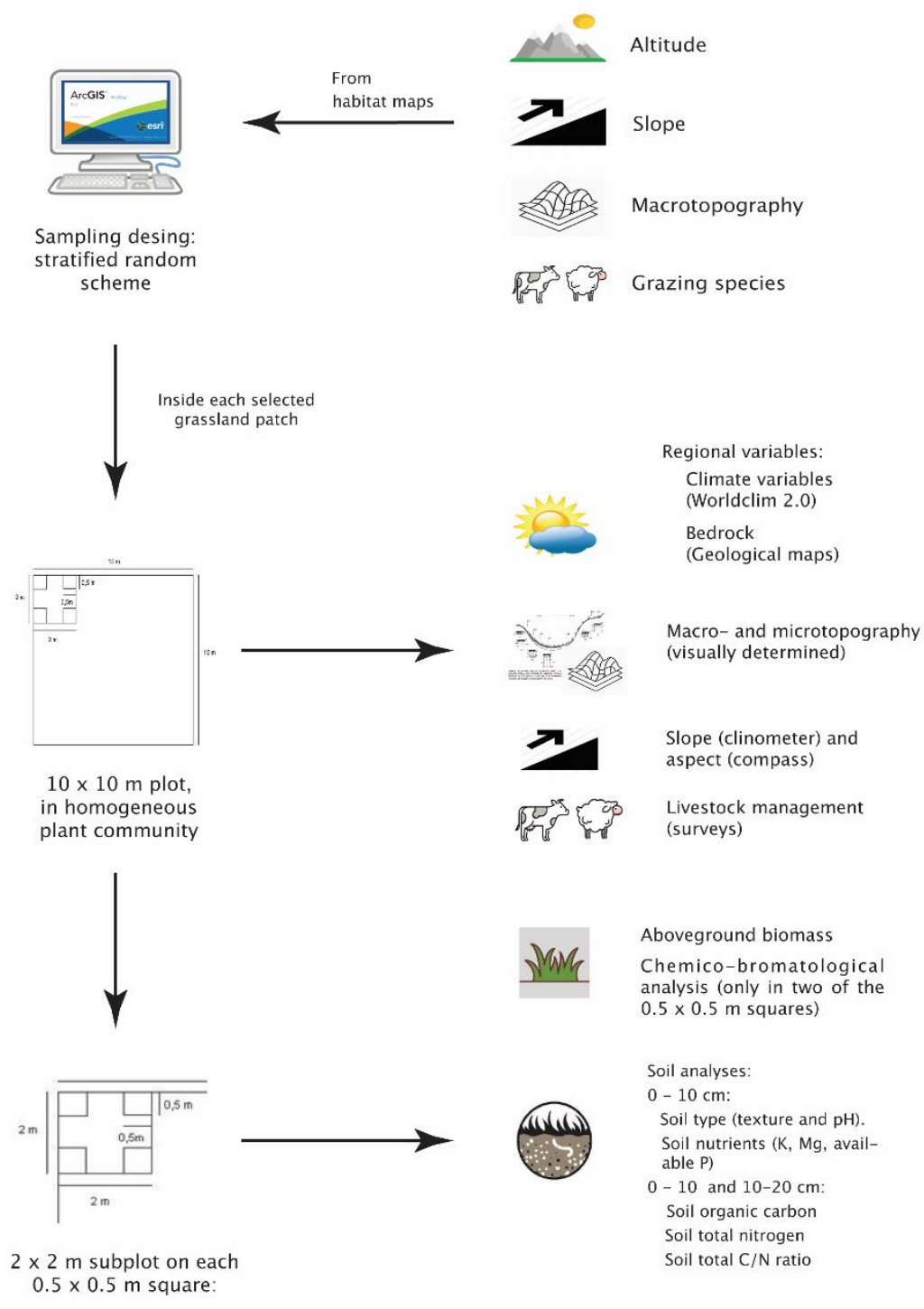


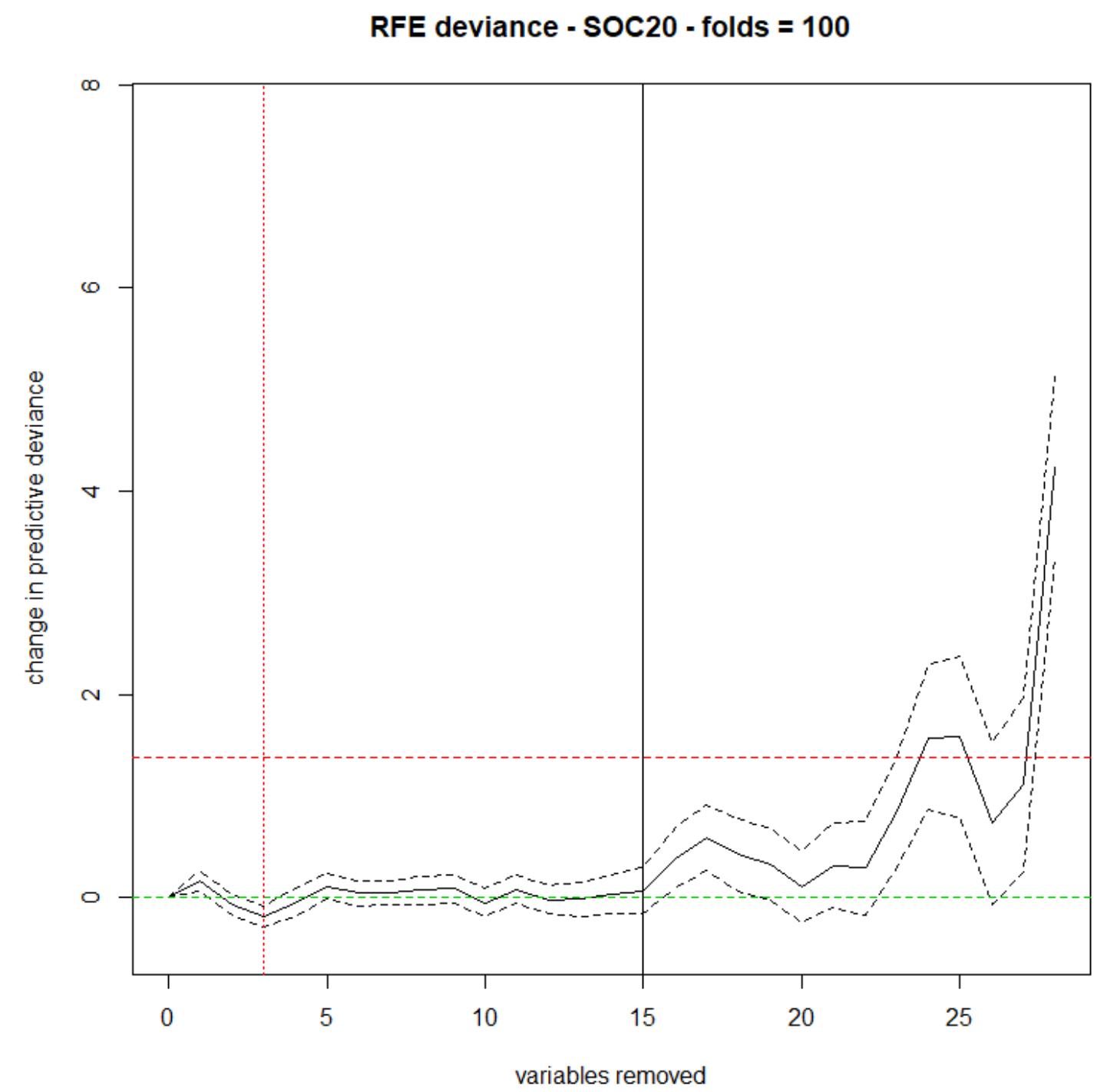

44 Figure S3: Changes in the predictive deviance of BRT models by backward removal of its

45 predictors. The solid line indicates the mean change in predictive deviance, and the dotted line

46 the standard error, calculated over the 10 folds of the cross-validation. Solid vertical line

47 indicates the variables removed for the second fit. Dotted vertical line indicates minimum

48 change in predictive deviance. Dotted horizontal line indicates mean change in predictive

49 deviance. 
A)

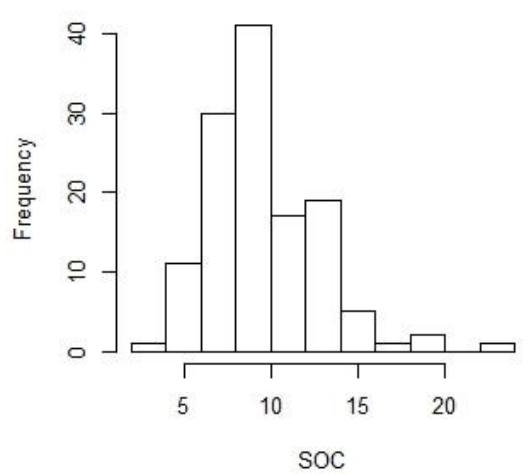

B)

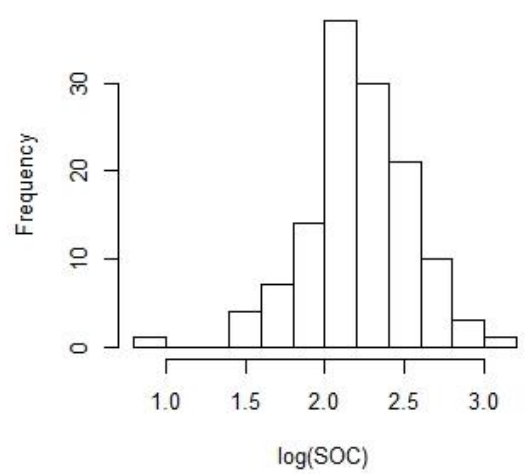

Normal Q-Q Plot

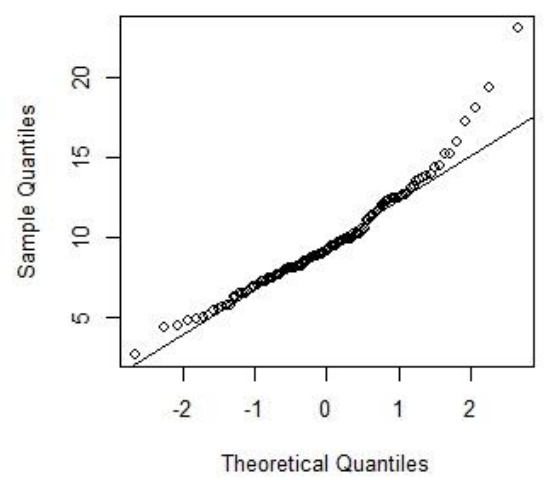

Normal Q-Q Plot

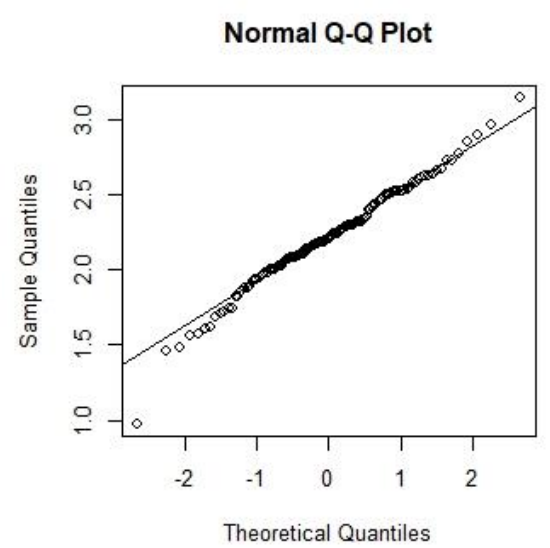

55

56 Figure S4: Histogram and normal Q-Q plot of A) SOC and B) $\log (\mathrm{SOC})$. Result of Shapiro Wilk W

57 test result were $\mathrm{W}=0.948 ; \mathrm{p}$-value $<0.001$ and $\mathrm{W}=0.99 ; \mathrm{p}$-value $=0.18$ respectively. SOC: soil organic carbon. 
A

\begin{tabular}{|c|c|c|}
\hline $\begin{array}{l}\text { Regional } \\
\text { Topography } \\
\text { Grazing management }\end{array}$ & Step 1 & $\begin{array}{c}\text { Geophysical } \\
\text { model }\end{array}$ \\
\hline $\begin{array}{l}\text { Regional } \\
\text { Topography } \\
\text { Grazing management } \\
\text { Soil type }\end{array}$ & Step 2 & \\
\hline $\begin{array}{l}\text { Regional } \\
\text { Topography } \\
\text { Grazing management } \\
\text { Soil type } \\
\text { Soil nutrients }\end{array}$ & Step 3 & $\begin{array}{l}\text { Combined } \\
\text { model }\end{array}$ \\
\hline $\begin{array}{l}\text { Regional } \\
\text { Topography } \\
\text { Grazing management } \\
\text { Soil type } \\
\text { Soil nutrients }\end{array}$ & Step 4 & \\
\hline
\end{tabular}

B
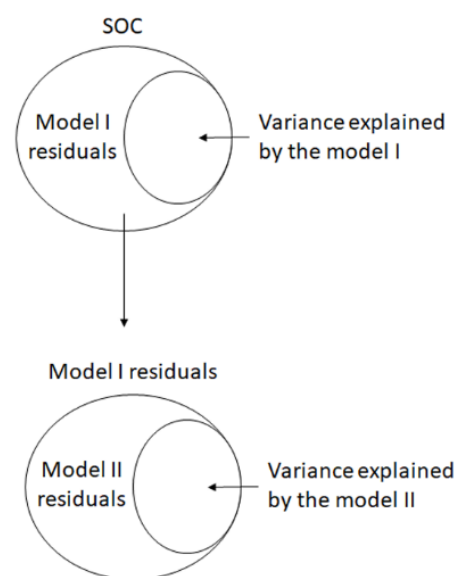

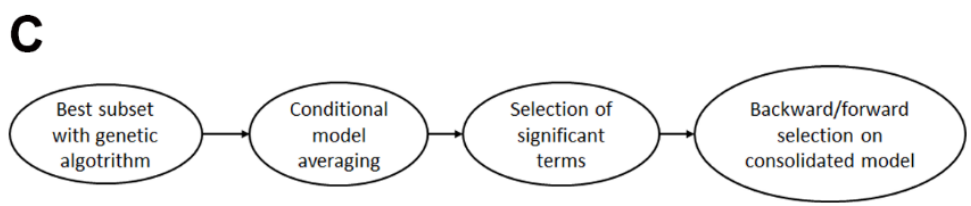

62

63 Figure S5: Linear modelling procedure. A) Variables introduced in each step. The first linear

64 model (Geophysical model) is fitted until Step 2 and the second linear model (Complete

65 Model) is fitted until Step 4. B) For selecting the candidate predictor terms on each step, residuals of the model obtained in the previous step are used as response variables in C. C)

67 Procedure to select candidate terms on each step. First, genetic algorithm was used to obtain a set of best models. Second, these models were averaged and the significant terms were selected as candidates for backward forward selection in the main/consolidated model. 


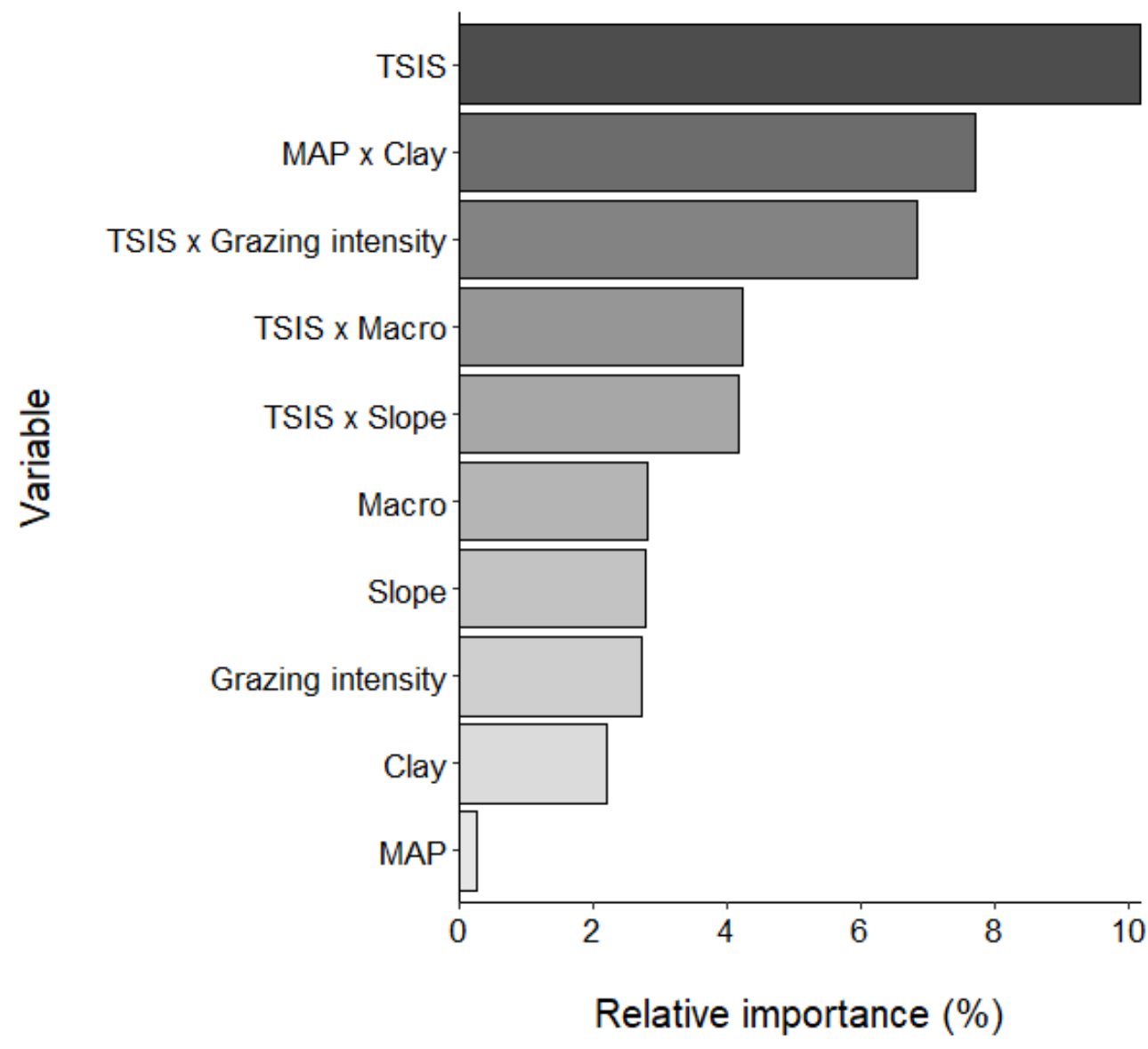

72

73 Figure S6: Relative contributions of variable groups in the linear model explaining Soil Organic

74 Carbon, using regional, landscape and management predictors. MAP: mean annual

75 precipitation; TSIS: mean summer temperature minus mean annual temperature; Slope:

76 terrain slope; Exposed: Exposed position according to Macrotopography; Clay: clay content;

77 Low and medium intensity: Low and medium intensity according to Grazing intensity. 


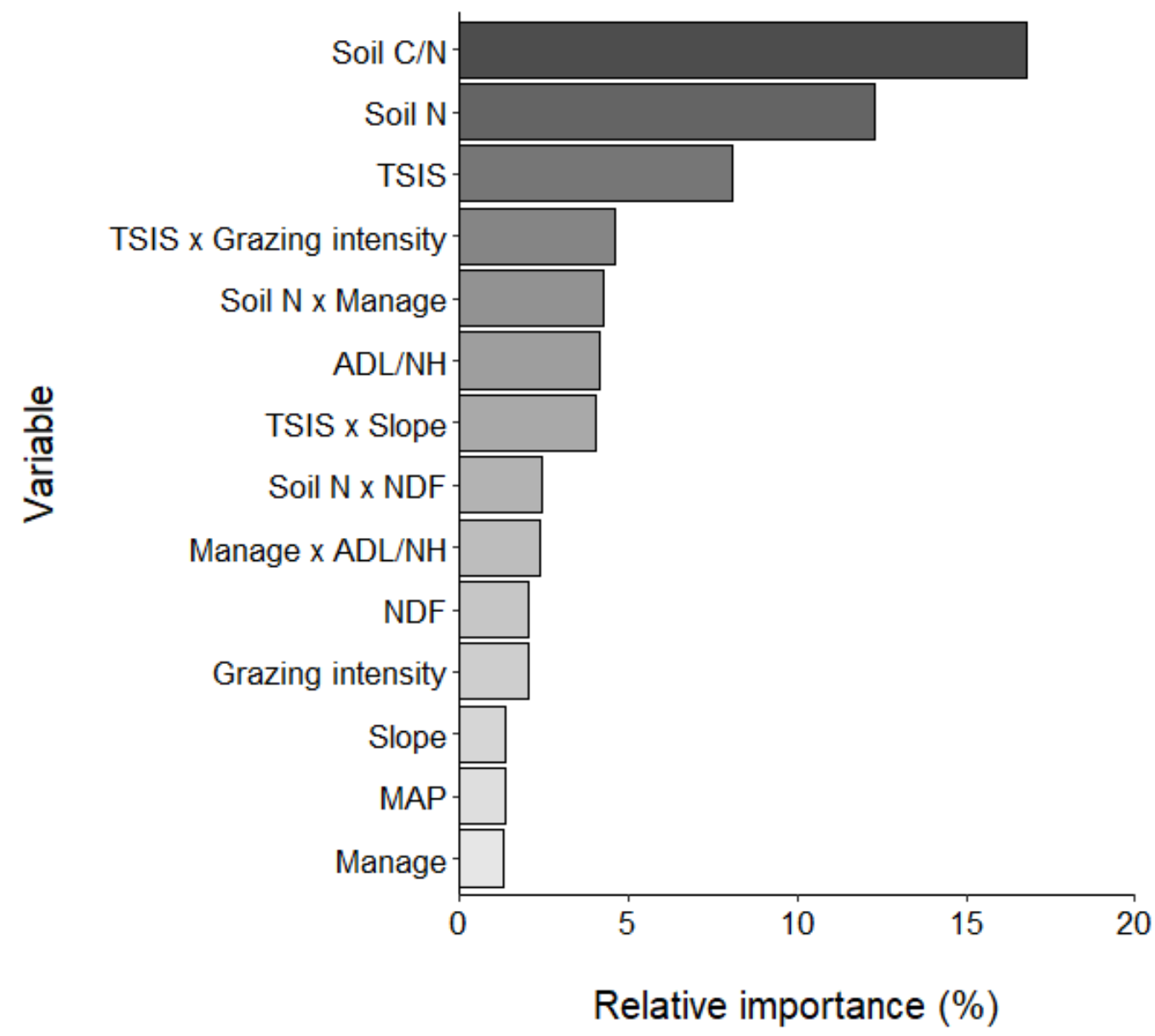

79

80 Figure S7: Relative contributions of variable groups in the linear model explaining Soil Organic

81 Carbon using regional, landscape, management and biochemical predictors. MAP: mean

82 annual precipitation; TSIS: mean summer temperature minus mean annual temperature;

83 Slope: terrain slope; Cattle and Mixed: Cattle and mixed management according to grazing

84 species; Low and medium intensity: Low and medium intensity according to Grazing intensity;

85 Soil C/N: soil carbon to nitrogen ratio; soil N: soil nitrogen; NDF: neutro-detergent fibre;

$86 \mathrm{ADL} / \mathrm{NH}$ : acid-detergent lignin to nitrogen in the herbage ratio.

87 

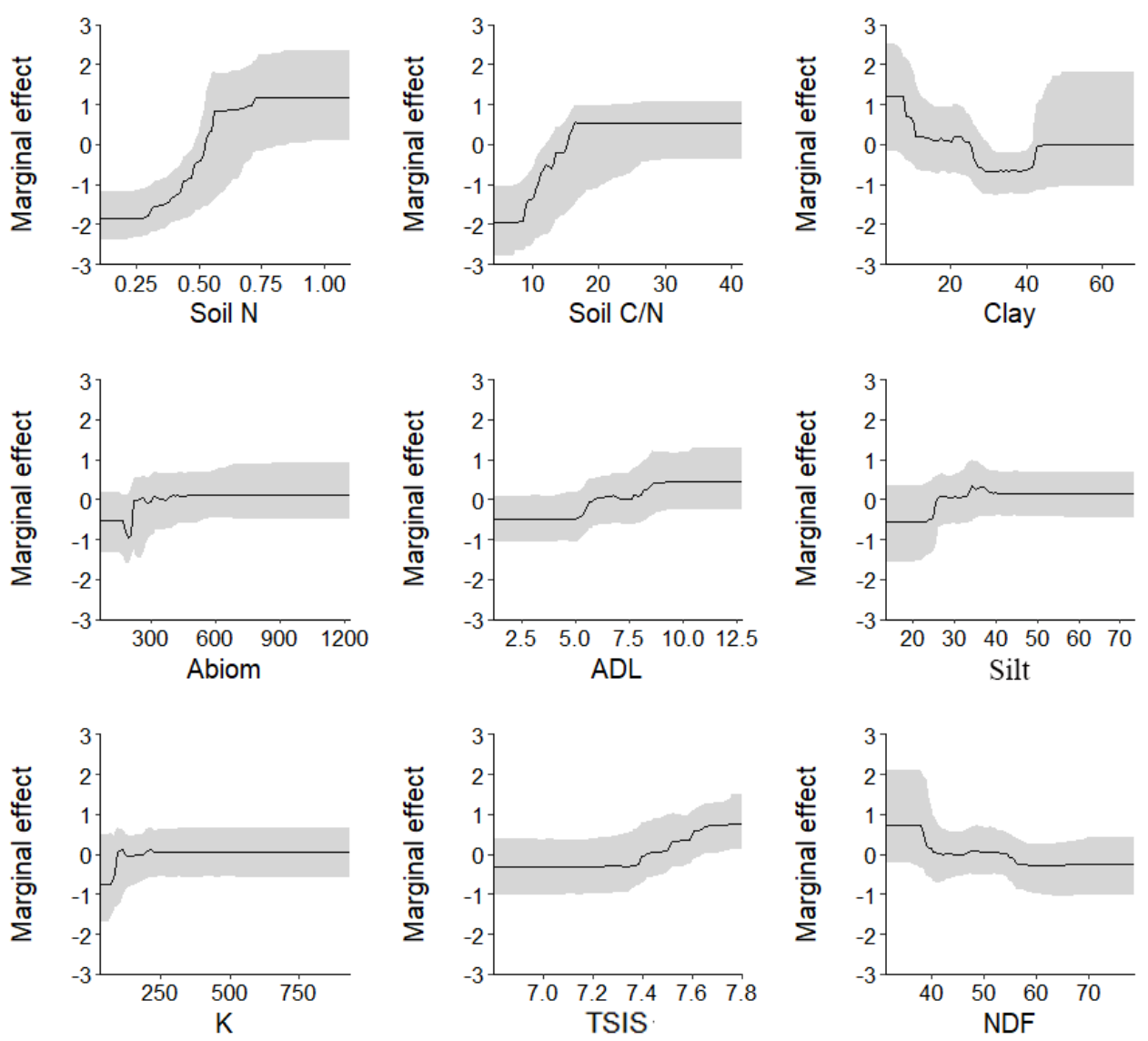

88
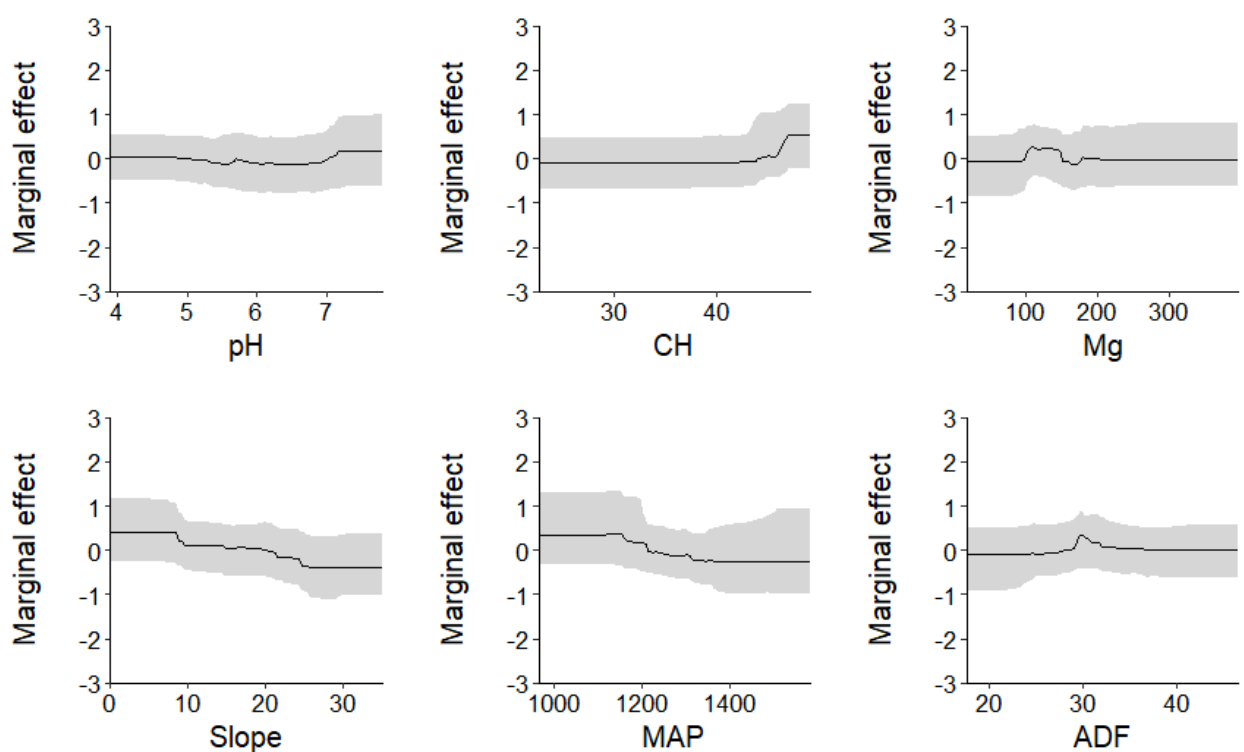

89 Figure S8: Partial dependence plots for the 15 selected predictors in the BRT model. Y axes are centred to have zero mean over data distribution. Values (solid lines) are predictions of the

91 model across the predictor's range maintaining the rest of the predictors at their average

92 values. Grey areas around prediction lines indicate $95 \%$ bootstrap confidence intervals. Soil N:

93 soil nitrogen; Soil C/N: soil carbon to nitrogen ratio, Clay: clay content; Abiom: aboveground 
94 biomass; ADL: acid-detergent lignin; Silt: silt content; K: soil potassium; TSIS: mean summer

95 temperature minus mean annual temperature; NDF: neutro-detergent fibre; $\mathrm{pH}$ : soil $\mathrm{pH} ; \mathrm{CH}$ :

96 carbon in the herbage; Mg: soil magnesium; Slope: terrain slope; MAP: mean annual

97 precipitation; ADF: acid detergent fibre. See Table S1 for more details about variables.

98 

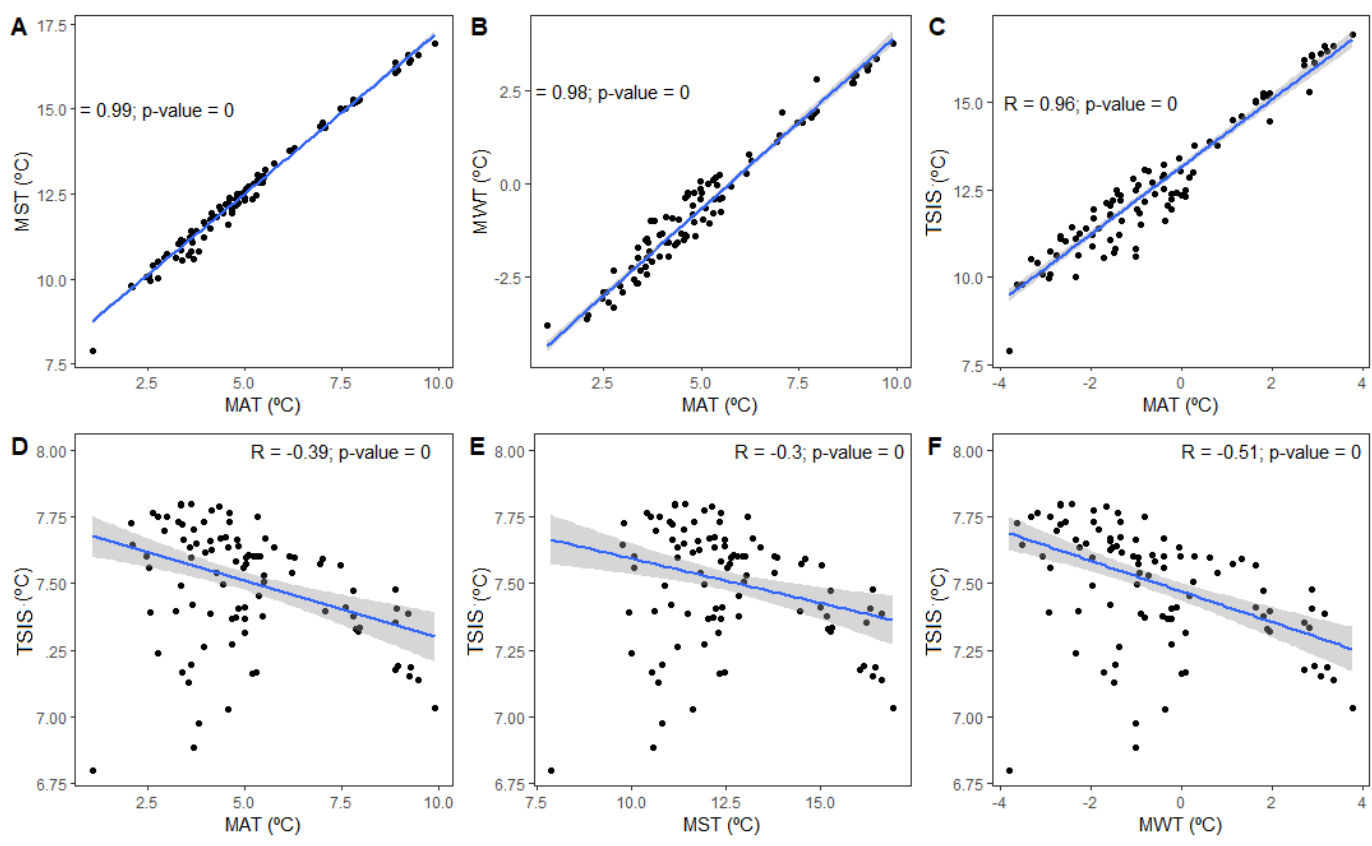

100 Figure S9: Pairwise Pearson's correlations between climate variables. MST: mean summer

101 temperature; MWT: mean winter temperature; MAT: mean annual temperature; TSIS: interannual seasonality measured as MST-MAT. 